\title{
The Role Of Local Loan Institution \\ In Providing Safety Net In Rural Area
}

(Case Study Loan Insitution in Cipendawa Village Pacet District Cianjur Regency)

\author{
Yogaprasta Adi Nugraha ${ }^{*}$, Mariana R.A Siregar $\left.{ }^{*}\right)$ \\ ${ }^{*}$ Universitas Pakuan, Bogor, Indonesia \\ Corresponding Author: yogaprasta_adinugraha@yahoo.com
}

\begin{abstract}
Rural area cannot be separated with poverty, according to Statistics Center Board (BPS), there are 18 milions rural people live below poverty line. Rural poverty has become many focus in development studies. There is a siginificant difference between rural poverty and urban poverty. Poor society in urban area are more vulnurable compared to poor society in rural area. In rural area, poor people tends to have informal social security that helps them to survive. This research aimed to determine the role of loan institution in providing social safety net for rural poor. Qualitative method was used to help us to have a better understanding about the debt institution in rural areas. This research found that rural poor have several alternatives source of debt that enable them to survive in a vulnerable situation. Most of people tend to see for a realistic loan institution with low interest (without interest is more preferable), low risk in returning the debt and fast in providing the money.
\end{abstract}

Keywords: Loan institution, poverty, social safety net.

\section{INTRODUCTION}

Study related to rural community be separated with rural poverty studies it is because rural area is identical with poor society. Poverty eradication is one of priorities in nasional development program in Indonesia. Based on Indonesia Statistic Board's data, there are approximately 28 milions people live below poverty line. This number shoud be our priority concern.

Poverty can occur in urban area and rural area, but there is a fundamental difference between urban poverty and rural poverty. In term of the number of poor people, rural area has much more poor people compared to urban area. According to Indonesia Statistic Board (BPS) 2013, there are about 10 million poor people in the City and 18 million poor people in rural areas. Moreover, in contrast to the urban poor relatively still have many job options, while the rural poor do not have many alternative jobs so their chances of getting out from the poor category are almost impossible.

In general, rural poverty is caused by several factors, but in general, poverty in rural area are due to (1) no natural resources supporting the community economic, (2) unequal relation between shareholders and communities, and (3) rural communities cannot access the viable resources of livelihood. These three things, and certainly still another factor, become a cycle that makes the people in rural are unable to accumulate capital and get out from poverty line.

Other factor that causes the increasing number of rural poor is the limited access into productive economic resources as well as income sources such as: community opportunities to plant cultivation and harvest crops are increasingly limited because their man power has already replaced by agricultural technology innovation. This condition tends to increase the number of poor people in rural area.

Poverty alleviation programs in Indonesia such as Direct Cash Transfer (BLT), Program Keluarga Harapan (PKH) are unable to exclude the poor to get out from poverty or to accumulate capital. The existence of such programs is only aimed to reduce the vulnerability of poor people when the crisis conditions invade Indonesia so that in the end, the poor people still able to survive.

Natural mechanisms of survival that commonly done by people such as investment or saving money are not a realistic option for poor people in. Practically, some of the coping strategy commonly done by poor people in rural area is saving in nonmoney forms such as raising chickens, goats, cows, participating in arisan, and loaning money. Loaning money is the most common survival activity of the rural poor.

Debt is an activity that frequently done by poor people in rural area. Normatively, the poor people are actually advised to borrow against non-burdensome loan sources, such as cooperatives or banks. But in 
reality, these sources are not easy to access by the poor. The poor are faced with non-realistic options such as, middleman and loan - sharks.

These incriminating sources are the last choice that will be chosen by the poor people in rural area. Before choosing a burdensome source of debt, the community will first choose the source of debt that is not burdensome such as owed to the nearest family and owed in the stall (Warung). Warung is a micro economic unit that is often found in various levels of the region from the RT, RW, Village, Village, and District. In this study Warung will be seen as one alternative to the rural social security system that is able to keep the rural poor from vulnerable conditions.

\section{Problem Statement.}

The number of poor people in rural area tends to stagnate and not decreasing this is a problem that must be resolved soon. The poor in rural areas are faced with the condition that so far there are no poverty alleviation programs that make people able to accumulate capital. In the absence of a poverty program capable of accumulating capital and macroeconomic conditions that are not enthusiastic, the rural poor are still able to survive and not fall into worse conditions.

There are many activities that can be done by poor people in rural area in order to survive in vulnerable conditions. The strategies they have taken to avoid falling apart are in the form of money is not a realistic option for the rural poor. Practically, some of the natural mechanisms that rural poor people often do to survive are saving in non-money forms such as raising chickens, goats, cows, participating in arisan, and loaning money. Loaning money is the most common survival activity of the rural poor.

Loaning to warung surely has its own rules of play, interaction patterns and norms. Therefore, based on the prior problem statement that has been stated, in general this research would like to see how the institutions (institutions) related to the activities owed in the stall. However, in more detail this research seeks to answer the following questions:

1. How is the role of rural institution in providing social safety net for poor houshold in rural area?

2. How is the poor people's accesibility in accessing loan institution in rural area?

\section{Research Objectives}

Based on the problem statement, this research objetives are: To Explain the poor people's accesibility in accessing loan institution in rural area.

\section{Social Institution}

Koentjaraningrat in Soekamto (2003) defines institutions as a system of governance and relations centered on activities to meet the complexes of special needs in people's lives. Meanwhile, according to Page in Soekamto (2003) institution is a procedure that has been created to regulate the relationship between humans.

In defining institutions, there are various perspectives, among others, according to Wiese and Becker (1982) who see the social institution from the point of view of its function, as a network of processes of relations between people and between groups of people. Unlike Weise and Becker, Summer in Weise and Becker (1982) looks at it from another point of view, the Culture point of view. Social institution is defined as a social institution as an act, ideals, attitude and cultural equipment.

Social institutions that aimed to meet basic human needs basically have several functions, namely:

1. Provide guidance to community members, how they should behave in facing problem.

2. To protect the group unity. Giving guidance to the community to hold a system of social control

In this study, institutions are not only limited to institutions that officially or formally institutionalized in the form of organizations but the institutions in this study are more to the social institutions that are running in the community both institutional institutions and institutions that are not in the form of organizations/institutions but still have institutional functions such as common goals, interaction patterns, and the existence of norms.

\section{Lending Activities}

Lend is one of habits in modern economic. Manning in Manara (2011) explains that the credit and debt system is one of the policies of the capital economic system in order that the production and consumption processes remains continue. Consumer loan disbursement is also needed so that the community helps to increase people's purchasing ability to buy goods and services. Lend can provide positive benefits for the economy but can also cause its own problems when the debtor fails to fulfill the obligation.

Lending activities cannot be separated from the concept of moral economy because the moral economy is an analysis of what makes a person act, and move in economic activity. Economic activity is expressed as a social phenomenon that is likely to affect the social life order. According to Evers in Damsar in Meivani and Arsal (2015), moral economic arises when they face problems in buying and selling activities. In lending activities, human beings are seen as creative beings. Human is trying to find a solution between personal interests and the interests of society. A trader has a dynamic morality, this is demonstrated in economic action that still cares for moral obligations and economic interests. Economic action is permitted on the basis of interactions between traders and customers. 


\section{RESEARCH METHODS}

\section{Research Design}

The method used in this research is a case study. Case Study is a detailed research about a person (individual) or a social unit for a certain period of time. This case study method has its own uniqueness or superiority in the social research arena. The Case study provides researchers with extensive access or opportunities for in-depth, detailed, intensive, and comprehensive review of the social unit under study. Case studies can also reach the smallest social units such as associations, groups and other forms of social units.

\section{Time and Location}

The location of the study was chosen purposively with some consideration (purposive). Cipendawa Village was Chosen as research location. There are some considerations in selecting Cipendawa Village as research location, namely: (1) Cipendawa Village representing the village whose majority of farmers are farmers who works in other people's land, that is why farmers in Cipendawa are categorized vulnerable. (2) Cipendawa Village is one of vegetable production centers in West Java. According to the Department of Agriculture Food Crops and Horticulture in Cianjur Regency. Cianjur regency is one of seven districts / cities which pointed as is the center of horticulture production in West Java. This research has been conducted from January 2017 until June 2017. The research stages were divided into 5 main stages: Such as (1) preparing research proposal, (2) Conducting literature study, (3) field research, (4) compilation of research result (5) writing final report.

\section{Research Subject}

Research subjects in qualitative research are not called respondents but subjects in the research called informants, informants in qualitative research is not statistical samples that represent the population for the purposes of generalization of the population but selected based on the considerations and research objectives of developing concepts and theories (Sugiono, 2008). Determination of informants is done intentionally with consideration of households that are below the poverty line or beneficiaries of government programs such as Family Hope Program (PKH) or Cheap Rice (Raskin).

\section{Data Collection Techniques}

Observation is used to see the daily activities carried out by poor households in order to survive. In the meantime, in-depth interviews are used to obtain related information: (1) poor households' strategies for survival, (2) poor household patterns when indebted (3) rules applied by the lender in carrying out the indebtedness mechanism. Focus Group Discussions (FGDs) were conducted to get a complete picture of the interaction patterns, rules of the game, and the purpose of the indebted activities.

\section{Data Analysis}

Data reduction used as data analysis method. The Data that are collected from the field were reduced using matriks so that we can found the essence of the data. Data analysis had already done since the beginning of this research until the end of this research.

\section{RESULTS AND DISCUSSION}

\section{The Role Of Loan Institution In Providing Social Safety Net In Rural Area}

The variation of poor people loan activities will be greatly influenced by the context of the farm households, in this research found approximately nine variations of loan activities by poor households.

\section{Lending money from Main Family Members.}

This study found that to reduce vulnerability, poor farm households sought loans to families because there is no interest risk and could borrow quickly but sometimes, the amount money not as much as desired. Like Maman (38), he said that he prefers to lend money from close relatives or relatives who have excess money. This is because it is not burdensome and relatively safety. He also explained that is different if borrowed to moneylenders, although he can get more money but the interest and terror is also greater. Bibih (28) also explained the same thing, She was traumatized to lend to loan - sharks because they sometimes do not hesitate to rebuke the debtors with a loud voice that attracted the attention of neighbors around. It creates fear for Bibih's mother because she does not want to be humiliated just because of the loan

Lending money to close relative is the best option because there is no interest and the farmer can get the money quickly but the gained money sometimes does not match the amount of money needed. In this study found also poor households tend to lend to the core family such as children or siblings. Lending to family members also has several variations, either to a (1) non-core family such as to the aunt's uncle or cousin, (2) to the core family such as brother, sister, and even child. Both variations also have different consequences, in general they will try to borrow first to the core/main family because it has a very small risk moreover there is a chance for the farmer to not returning the money, while non-core families still have an obligation to return the money though without interest.

As Maman (38) did, when in his famine days he lent money to his three children without worrying about having to return the money because his three children worked as Civil Servants. Similarly, what is expressed by Olis (53), if there is increase in the cost of daily goods or famine, he prioritizes the purchase of rice and daily hygiene needs along with side dishes. When he needs a loan, usually he borrows money to his son named Hari (stall owner). 


\section{Lending Money from Landlord}

This study found that in addition lending to families, there are poor households who lend money to work relatives who have patron-client relationship, for example like borrowing to landlords or those who employ poor households. As Hendar (40) puts it, he says that sometimes there are workers who borrow money for sudden day-to-day needs such as paying for school books or having sick family members, but usually the loans are not so large at around Rp. 250.000 sd Rp.500.000, usually the return mechanism are varies depending on the agreement with the borrower, some are taken Rp. 50,000 of each paid. In addition there is also Jejen (40) who said that when he was in a famine condition he lent from superiors, the returning payment system usually later after the harvest time is coming.

These two conditions, describe the form of the client's patron relationship. The client's patron is the exchange of relations between the two roles that can be expressed as special cases of ties involving instrumental companions in which an individual with a higher socio-economic status (patron) uses his influence and resources to provide protection, as well as benefits to a person with the status he considers to be lower (client). The client then responds by offering general support and assistance including personal services to his patron. As the scattered patterns of exchange, services and goods exchanged by patrons and clients reflect the emerging needs and resources of each party. In the first case, Raden (40) years as a capital (patron) provides loan money assistance to farmers who need money (clients) with the aim that the farmer is loyal to work on him, because in Cipendawa Village there is now the difficulty of agricultural labor so the behavior of lending money can be seen as a behavior that binds the farmer to keep working on him. Meanwhile, farm laborers (clients) give their commitment to keep working for Gapoktan (Gabungan Kelompok Tani).

\section{Lending Money from Middleman}

This study found that farm households lend money from middlemen, Jejen (40) when facing difficult times he usually make loans to middlemen without interest. But farmers are obliged to sell their crops to middlemen who provide loans with a cheaper price. Currently the middlemen usually buy at a price varying 10-30 percent smaller than the standard given. That way, farmers can easily borrow money to the middleman in case of crop failure or famine. Indeed, this system offered by middlemen, farmers are allowed to borrow money but the farmer must sold the product to the middleman with lower price. Besides lending to middleman, farmers can sometimes borrow money from large traders or retailers and paid their loan with agricultural products. Jejen (40) said that he often make loans to the Bandar, which meant Bandar is a middleman who deliver the harvest to the market, with the other term Bandar is a big middlemen. The loan repayment system is usually done with yarnen-system (bayar panen) and it is subjected to a 10 per cent discount on the yield. Jejen is also known to work as a middleman in his village, so he also provides loan assistance to the farmers if the condition of the farmers economy is stable or possible. As a middleman he provide loan assistance on terms of repayment of loans using the system yarnen, so it can be concluded that the farmers who need loans from middleman must sell their crops. If not, the middleman said he would not give any loan assistance.

In Cipendawa there are approximately 10 middlemen, this condition makes the competition between middlemen became increasingly tight. Giving lend to farmers becomes a strategy for middleman in order to make farmers sell their goods to them. The tight competition lowering middleman bargaining position, now farmers are considered smart because they can directly check the checks to wholesalers in the market. This reality makes the middleman must have a specific strategy to be able to bind farmers.

\section{Lending Money from Loan - Sharks}

Nowdays, people in Cipendawa village are rarely lend to loan - sharcks, because they already knew the consequences from lending to loan - sharks. Although, there are not much people who still lending money from loan - sharks, there are still loan - shark who offers lending in Cipendawa, but there are no people want to lend to loan - sharks. The image of loan - sharks has already damaged due to the information that spread in society. Loan - sharks tends to charge a high interest to their creditor. Bibih (28) gives an illustration, if she borrows Rp 500,000, she will only get $\mathrm{Rp} 450,000$ (at the beginning, the loan already deducted $\mathrm{Rp} 50.000$ ) and when she wanted to pay the loan, she must return the loan Rp 750.000 (Interest rate can reach 50\%). Another explanation that loan shark has been abandoned because there is negative experience if the creditor late to pay the loan shark, as expressed by Bibih (28), In case of late payment, the loan -sharks will not hesitate to rebuke the debtor loudly so attract attention neighbors around.

\section{Lending Money From Formal Bank Institution}

Every level of society has their own loan alternatives. In this research we found that rich farmers tend to have higher amount of loan compared to poor farmer. The main objective of rich farmer's loan is for accumulating their capital so that they can expand their landownership. This is the reason why rich farmers have to had a bigger loan institution like formal bank institution with their complex requirement. There is an example of rich farmers (Landlord) who lend to Bank, Raden (40), he owned $8 \mathrm{Ha}$ of farmland, He lend 1 Billion Rupiahs from Bank and give his land sertificate as guarantee with 3 years repayment period. Raden (40) also said that he used the money to buy a farmland. This research also found that there was a 
farmer who lent to Bank Perkreditan Rakyat (Society Credit Bank/BPR) and used his motorcycle certificate as a loan guarantee.

Credit offered by the bank is not attractive to farmers because of several factors, among others: (1) Guarantee system is considered burdensome because small farmers have no guarantee. (2) The monthly installment system is considered unrealistic because the farmer's income system has to adjust to the harvest time. (3) There is a more realistic debt alternative for smallholders. (4) Small farmers are tied to other loan institutions such as middlemen, landlords, and fertilizer agents. This kind of conditions makes limited the participation of small farmers to bank credit.

\section{Lending Money From Farmers' Association}

This study found there was a farmer who lent money from farmers' association (Gapoktan). Edi (33) said that he usually lend money for daily needs sometimes it can ranged from 1-3 million rupiahs. He prefers to lend money from farmers' association (Pak Edi is incorporated in Gapokawa farmers association Cipendawa village, Cianjur). The reason is because it is easy to lend money from farmers' association and the repayment mechanism is fair and realistic. The loan will be return in accordance with the nominal amount lent according to the agreed time limit between the debtor and the creditor (without interest / familial and mutual cooperation system).

Gapoktan Mujagi has approximately 80 members. According to Didin (33) there are requirements to join Gapoktan, among others, member must have money deposit if they want to join this farmers association. In 2009 informants began to join in Gapoktan and subjected to a money deposit of Rp.300.000, - and at this time in 2017 has been agreed on a deposit become Rp.500.000, -. Other conditions such as giving a monthly fee Rp.25.000, - The monthly budget is deposited in order to provide capital loans to farmers who are members.

\section{Warung as Favorite Place to Lend}

Warung is a informal shopping place where can be found throughout the village. Warung is chosen by farmers due to the location and easy to be accessed. However, although it is relatively easy to lent goods from warung, but there is a regulation that the maximum amount of lend cannot be more than 50.000 rupiahs. The poor household admitted that they only lend cigarette and snacks. The repayment period usually only 1 week before Harvest (Yarnen - Bayar Panen)

As stated by Didin (33), he said that the lending to warung was unexpected, when he wants to buy cigarette but in other hand he did not bring money, but after farming he would soon pay it off. As expressed by Edi (33), he lent to warung if he really needs, usually to buy instant noodles or sugar coffee, but the amount does not exceed than 50,000. In addition to Edi, there is also Olis (53), in urgent condition she lends to the warung. The mechanism is when the she has a shortage of payment when shopping it will be included in the book of debt. The limit provided is $\mathrm{Rp} 50,000$. In general, farm households choose to indebted to the nearest warung, because it is easy to reach, the owner of the warung is more confident because only recognized people can lend to warung.

This research found that Warung is the most favorite place for farmer to have loan. Instead of lending money farmer perfer to lend goods like noodle, cigarette, and sugar. Ibu Kokoy (42), she is owner of one of warung in Cipendawa, she have operated warung since 1993, she said that at the begining there was only 3 warung but after 2005 there are more than 30 warung in Cipendawa.

Mrs. Kokoy says that not everyone can lend to her warung In general, people who can lend to her warung are family or close / familiar neighbors with good credibility. She said that in the context of horticulture farming, farmers are not only planting one kind of plant, but also various types of plants with different planting periods so that they can predict when the will get money.

\section{CONCLUSION}

Conclusion in this research are:

1. Loan Institution in rural area can provide safety net for poor people in rural area to protec them being more vulnerable.

2. There are 7 loan Institution in Cipendawa village, but only 4 of it thats accessible for poor people in rural area, (1) Main Family (2) Landlord (3) Middleman (4) Warung. These 4 Loan Institution are accessible for rural poor. Meanwhile the other 3 Institution, Bank, Farmers Association, and Loan Sharks are not accessible due to the burdensome requirements.

Recommendations for this research are:

The village fund is under the authority of the village office have to able to create a security system in the village by strengthening Gapoktan or cooperative so that these two institution will be able to be accessed by poor household. In Cipendawa village, the existence of Gapoktan important, but because their capital is limited and the requirements are burdensome not all farmers can access loan from Gapoktan. Village funds are expected to strengthen the Gapoktan capital so that they can provide assistance to the farmers.

\section{REFERENCES}

Badan Pusat Statistik. 2013. Kemiskinan Pedesaan dan Perkotaan: Jakarta.

Nugraha, YA. 2012. Hubungan Orangtua, Media Massa, dan Teman dengan Sikap Pemuda Terhadap Pekerjaan di Bidang Pertanian (Kasus 
Pemuda di Cipendawa dan Sukatani Kecamatan Pacet Kabupaten Cianjur). Bogor (ID): Institut Pertanian Bogor

Nugraha, Y dan R, Herawati. 2015. Menguak Realitas Orang Muda Sektor Pertanian di Pedesaan. Jurnal Analisis Sosial: Vol 19 No 1. Akatiga: Bandung

R.W Connel. 1997. Why is Classical Teori Classical? The American Journal of Sociology. Vol 106 No. 6. May 1997. 1511-1557

Singarimbun, M dan S, Effendy, 1995. Metode Penelitian Survai. Penerbit LP3ES, Jakarta

Soekanto, S. 2003. Sosiologi: Suatu Pengantar. Rajagrafindo Persada, Jakarta.

Valdiani D, Nugraha YA, Siregar MRA. 2017. Attendance of Mass Media and Parents in Defining the Value of Agriculture in The Eyes of Rural (Case Study of Rural Youth at Horticulture Center in Cianjur Regency) 